\title{
Prostat Kanseri Tedavisinin Geleceği Apoptotik indükleyicilerde mi?
}

\section{Does the Future of Prostate Cancer Treatment Lie with Apoptotic Inducers?}

\author{
Dr. Ece Konaç1', Dr. Sinan Sözen² \\ ${ }^{1}$ Gazi Üniversitesi Tıp Fakültesi, Tıbbi Biyoloji ve Genetik Anabilim Dalı, Ankara, Türkiye \\ ${ }^{2}$ Gazi Üniversitesi Tıp Fakültesi, Üroloji Anabilim Dalı, Ankara, Türkiye
}

\section{Öz}

Genel sağkalım süresini uzatabilen günümüz klinik başarılara rağmen, prostat kanserine (PK) bağlı mortalite halen önemli bir sorundur. Yüksek düzeyde genetik ve klinik heterojenlik gösteren metastatik kanser hücrelerinin en önemli özelliklerinden biri de, apoptozise dirençli olmaları ve nihayetinde progresif hastalığın gelişmesine neden olmalarıdır. Dolayısıyla, PK'nin lokal tedavisinde alınan yol, metastatik hastalığın tedavisinde henüz yakalanamamıştır. Metastatik olgularda, birincil önemi olan androjen reseptör (AR) sinyal yolaklarından dolayı androjen deprivasyon (baskılama) tedavisi standart tedavi olsa dahi, AR'lerinin genetik aberasyonları sonucu tedavide başarı yakalamak oldukça zordur. Ortalama 12-36 ay içinde PK'li hastaların çoğunluğu androjen ablasyonuna direnç geliştirmekte ve kastre düzeydeki testosterona rağmen androjen bağımlı/bağımsız sinyaller, kanser hücrelerinin çoğalmasına sebep olmaktadır. Metastatik kastrasyona dirençli PK tedavisinde abirateron, enzalutamid gibi yeni nesil ajanların etkin yaşam avantajları göstermesi umut verici olmakla birlikte; primer ve sekonder tedavi direncinin en iyi nasıl yönetileceği halen kaçınılmaz bir sorundur. PK tedavi direncinin üstesinden gelmek için, apoptotik etkileri arttırmayı hedefleyen sitokoruyucu şaperon ağlarındaki prosurvival efektörler ve apoptotik regülatörler her geçen gün önem kazanmaktadır. Apoptotik yolağı indükleyen mekanizmaları konu alan yeni bilimsel araştırmalar, sinerjistik tedavi stratejilerinin geliştirilmesinin önemi üzerinde yoğunlaşmaktadır. Gelecekte kemoterapötiklerin yerini, apoptozis gibi fizyolojik mekanizmaları çalıştıran, yan etki profili düşük moleküllerin alması öngörülmektedir.

Anahtar Kelimeler: Apoptozis, anti-şaperon ajanlar, tedavi direnci, prostat kanseri

\begin{abstract}
Despite present-day clinical achievements which can extend the overall survival period, prostate cancer $(\mathrm{PCa})$ related mortality remains a major problem. Resistance against apoptosis which consequently leads to disease prognosis is one of the most important characteristics of metastatic cancer cells which display a high level of genetic and clinical heterogeneity. Therefore, achievements in the local treatment of PCa have not been matched in the treatment of the metastatic disease. Although androgen deprivation therapy is the standard treatment due to the androgen receptor (AR) signaling pathway which has primary importance in metastatic cases, successful treatment remains difficult because of the genetic aberrations of ARs. Majority of the PCa patients develop resistance against androgen ablation within an average of 12-36 month-period and despite the castrate levels of testosterone, androgen-dependent and independent signals cause an increase in the cancer cells. While effective survival advantages displayed by the new generation agents like abiraterone and enzalutamide is promising in the treatment of metastatic castration resistant PCa how to best manage the primary and secondary resistance to treatment remains a challenge. The apoptotic effect enhancing pro-survival effectors and apoptotic regulators within the cytoprotective chaperone networks become more and more important every day for overcoming treatment resistance. Recent scientific research on apoptotic pathway inducing mechanisms focuses on the importance of developing synergistic treatment strategies. Molecules with lower side-effect profiles which are capable of inducing physiological mechanisms like apoptosis are expected to replace chemotherapeutic agents in the future.
\end{abstract}

Keywords: Apoptosis, anti-chaperone agents, treatment resistance, prostate cancer

\section{Giriş}

Embriyonik gelişim ve homeostazis için gerekli olan apoptotik sinyal yollarındaki fonksiyon bozukluğu; prostat kanser (PK) progresyonu ve tedavisindeki direnç ile ilişkilidir. Bundan dolayı, etkin apoptotik yanıt üretimi kastrasyona dirençli PK (KDPK) tedavisine yönelik önemli bir terapötik potansiyeldir. Abirateron asetat, enzalutamid, kabazitaksel ve radyum-223 diklorür, hormonal terapötik, kemoterapötik ve radyofarmasötik rolleri bilinen ve günümüzde tedavide etkin olarak kullanılan ilaçlardır. Ancak, bu yeni nesil ajanlar dahi yüksek düzeyde heterojenite gösteren kastrasyona dirençli grubun kötü progresyonunun önüne geçememekte; birincil ve ikincil terapilere karşı direnç gelişmektedir (1). Bu durumun üstesinden gelmek için, tümör hücrelerinin sağkalımını sağlayan sitokoruyucu şaperonlar hedef alınarak, apoptotik yanıtı arttıran tedavi 
yaklaşımları geliştirilmekte ve hücre ölümü sinyalleri arasındaki dengenin kurulmasıly homeostatik apoptotik çevrenin yeniden oluşturulması amaçlanmaktadır $(2,3,4)$. Ayrıca, ısı-şok proteinlerini (HSP) bloklayarak androjen reseptörlerini (AR) destabilize etmek tedaviye yönelik geliştirilen stratejilerden bir diğeri olmuştur (5). Derlememizde, apoptozis için gerekli iç ve dış sinyalleri doğrudan hedef alan ve sitokoruyucu şaperon proteinlerinin ifadelenmesini engelleyen yeni nesil ajanların güncel durumu gözden geçirilecektir.

Ekstrinsik (Dışsal) ve İntrinsik (İçsel) Apoptotik Sinyal Yolları Apoptozis, fonksiyonel olarak bozulmuş hücrelerin ortadan kaldırıması için pro-apoptotik ve anti-apoptotik moleküllerin zıt etkileşimleriyle düzenlenen programlanmış hücre ölümüdür. Apoptotik hücre ölümü, kaspazlar olarak bilinen sistein proteaz enzimlerinin, hedef hücresel substrat proteinleri aspartik asit birimlerinden kesmesine dayanan hücresel bir süreçtir. Kaspaz aktivasyonu ile sonuçlanan apoptotik yolakların iki ana şekli olup, bunlar:

1. Ekstrinsik (dışsal, ölüm reseptörü) yolak; kaspaz 8'in aktivasyonunu kontrol eden hücre yüzeyindeki tümör nekroz faktörü (TNF) süper ailesine ait FAS, TNF reseptörü 1 ve TNF-ilişkili apoptozisi indükleyen ligand (TRAIL) gibi ölüm reseptörlerinin aktivasyonu ile başlar.

2. İntrinsik (içsel, mitokondriyal) yolak ise; mitokondriden salınan sitokrom C ve küçük mitokondri türevli aktivatör kaspazları (SMAC)/DIABLO proteinleri ile tetiklenir. Bu proteinler, kaspaz 9 ve efektör kaspazlar olan kaspaz 3 ve 7'nin aktivasyonu ile birlikte çalışır. Kaspaz 9'un aktivasyonu sitokrom C'nin Apaf-1 proteinine bağlanması sonucu oluşturulan apoptozom kompleksinin kurulması ile sürdürülür.

Dış yolak hücre yüzeyinde bulunan ölüm reseptörleri tarafından başlatılırken; iç yolak stres, yetersiz sitokin desteği, farkı tipte hücre içi hasarlar gibi olaylar tarafından uyarılır. Ancak, bu iki yolak, efektör kaspazların etki noktasında birleşir $(6,7,8)$. Bir diğer deyişle, apoptozisin içsel ve dışsal yollarında mitokondriyal aktivasyon kesişim basamağıdır. Bundan dolayı, sitokrom C'nin dış mitokondri zarından sitozole salınması ile meydana gelen mitokondriyal aktivasyon apoptotik süreçte çok önemli bir mekanizmadır.

B-hücre lenfoma-2 (Bcl-2) ailesi üyeleri, hem apoptotik hem de anti-apoptotik proteinleri içerir ve apoptozun temel mitokondriyal yolağını düzenler. $\mathrm{Bcl}-2$ protein ailesi apoptozisi inhibe eden (BCl-2, Bcl-xL, Mcl-1, Bcl-w, A1/Bfl1 gibi) veya aktive eden (Bax, Bak, Bad, Bim, Bik, Noxa, Puma, Hrk gibi) birbirleri ile yüksek oranda yapısal homoloji gösteren proteinlerden meydana gelmiş bir ailedir. Bu protein ailesinin farklı üyeleri arasındaki ana benzerlik, Bcl-2 homoloji (BH) bölgeleri ile karakterizedir. Yapısal olarak ise $\mathrm{BCl}-2$ üyesi proteinleri, $\mathrm{BH}-3$ bulunup bulunmamasına göre üç alt sınıfa ayrılır. Apoptotik Bcl-2 proteinleri, yalnızca BH-3 bölgesini ifade eden "sensitizör (katalizleyici)" ve tüm $\mathrm{BH}-1, \mathrm{BH}-2, \mathrm{BH}-3$ ve $\mathrm{BH}-4$ bölgelerini ifade eden "aktivatörler" olmak üzere ikiye ayrlırken; antiapoptotik $\mathrm{BCl}-2$ proteinleri ( $\mathrm{BCl}-2, \mathrm{BCl}-\mathrm{w}$ ve $\mathrm{Mcl}-1)$ ise, $\mathrm{BH}-1$, $\mathrm{BH}-2$ ve $\mathrm{BH}-3$ proteinlerini ifade eder. $\mathrm{BH}-1, \mathrm{BH}-2$ ve $\mathrm{BH}-3$ bölgeleri, ölüm sinyali aktivasyonu veya inhibisyonunda kritik bağlanma bölgeleri oluşturur. Bu iki zıt etkili grubun işleyişi yapılarında bulunan iki bölgeye (hidrofobik cep ve amfipatik a-heliks) bağlıdır. Yapılarındaki BH-1, BH-2 ve $\mathrm{BH}-3$ bölgeleri hidrofobik cep'i oluşturur. Amfipatik a-heliks, BH-3 bölgesinde yer alır. Hidrofobik cep sayesinde bir diğer $\mathrm{Bcl}-2$ ailesi üyesinin BH-3 bölgesine bağlanırlar. Sensitizör proteinler (Bad, Bim, Bid, Noxa, Puma, Hrk) hasar sensörleri olarak davranırlar ve stres sinyali gelmedikçe inaktif formdadır. Aktivasyon ile birlikte bu $\mathrm{BH}-3$ proteinleri, sağkalım proteinlerine (Bcl-2, BCl-cL, Bcl-w, Mcl-1, A1/Bfl1) bağlanır ve bu proteinleri inaktive eder. Eğer sensitizör Bcl-2 proteinleri aktive olmazsa, apoptoz başlamaz. Bu sinyal ağı, yeni gelişmekte olan apoptotik ajanların hedeflediği bir tedavi stratejisidir $(9,10,11)$.

Prostat Kanserinde Apoptotik Yolağı Hedef Alan Ajanlar

Androjen bağımsız PK fenomeninde olduğu gibi, malignite riskinde artışla birlikte hücrelerin apoptosize karşı direnç geliştirmeleri kaçınılmaz bir sondur. Kaspaz aktivitesini engelleyen inhibitörler, Bcl-2 kontrol noktalarına müdahale eden moleküller, SMAC taklit eden moleküller, anti-şaperon antisens ajanlarının kullanımı, halihazırda klinik olarak değerlendirilen yaklaşımların başında gelmektedir (2). Ayrıca, uzun kodlanmayan RNA'lar (IncRNAs); PK'sinde up-regüle (aşırı ifadelenen) olduğu bilinen PCA3, PCATs, SChLAP1, SPRY4-IT1 ve TRPM2-AS genlerinle ilişkili olduğu için, tanı ve tedavide yeni hedefler kapsamına girmiştir (12).

\section{1. İçsel Yolak İnhibitörleri}

Bu sınıftaki inhibitörler için kullanılan Bcl-2 inhibitör terimi, hücre yaşamını teşvik eden protein ailesi üyelerini bağlayan ilaçları kapsamaktadır. Klinik geliştirme çalışmalarında, BCl-2 antisens bileşenleri ve küçük molekül BH-3 mimetikleri olarak iki stratejiden bahsedilmektedir. Antisens terapi, hedef gen ürünlerinin ( $\mathrm{BCl}-2$ ve $\mathrm{BCl}-\mathrm{xL}$ ) ifadelenme düzeyini sınırlarken; $\mathrm{BH}-3$ mimetikleri ise $\mathrm{BCl}-2$ veya $\mathrm{BCl}-\mathrm{xL}$ gibi anti-apoptotik proteinlerin pro-apoptotik $\mathrm{Bax}$, Bak gibi proteinlerle heterodimerizasyonunu inhibe ederek apoptozun ilerlemesini sağlar (9). Üstelik, DNA antisens ve/veya RNA interferaz gibi nükleik asit bazlı terapötiklerin (nanopartiküller) kullanılmasında, proteinin inhibisyonu değil (çoğu kemoterapötik ilaç proteinlere bağlanır), proteinin oluşmadan önceki transkripsiyon veya translasyon aşamasının inhibisyonu amaçlandığı için yeni moleküler düzenleniş engellenmiş de olur.

\section{Oblimersen (G-3139; Genasense; Genta Inc)}

$\mathrm{BCl}-2$ ekspresyonunu hedefleyen klinik denemelere giren ilk ajan olan oblimersen, sentetik olarak modifiye edilmiş DNA antisens oligonükleotidi olup; Bcl-2 mRNA'sı ile hibrid oluşturarak $\mathrm{BCl}-2$ proteininin translasyonunu engeller. Dosetaksel terapisinden önce veya mitoksantron ile kombinasyonlu faz 1 ve 2 çalışmaları, ümit verici sonuçlanmışır (13). Illerleyen faz 2 denemesi, metastatik kastrasyon dirençli PK'li 115 hasta ile gerçekleştirilmiştir. Hastalara, dosetaksel $\left(75 \mathrm{mg} / \mathrm{m}^{2}\right)$ tek olarak veya oblimersen ile kombine $(7 \mathrm{mg} / \mathrm{kg}$ ) olarak 1-7 gün aralığında uygulanmışır. Doğrulanmış prostat spesifik antijen (PSA) yanıtlarl; dosetaksel grubunda 26 hastada (\%46) ve dosetaksel + oblimersen grubunda 20 hastada (\%37) gözlemlenmiştir. Ölçülebilen, Response Evaluation Criteria in Solid Tumors (RECIST, Kanser Terapi Yanıt Değerlendirme) değerlerine göre dosetaksel grubunda kısmi cevap, 28 hastanın 5 'inde (\%18) ve dosetaksel + oblimersen grubunda 21 hastanın 5 'inde (\%24) elde edilmiştir. Sınıf 3 ve üzeri olgulardaki yan 
etkiler tedavi grupları arasında dengede iken, dosetaksel + oblimersen grubunda, güvenlik profili (temel olarak yorgunluk, mukoza iltihabı ve hematolojik toksisite) dosetaksel grubuna göre kötüye gitmiştir. Dolayısıyla, klinik çalışma sonlandırılmıştır (14).

\section{Gossypol (AT-101)}

Pamuk bitkisinden elde edilen doğal fenol bileşik olan gossypol, oral $\mathrm{BH}-3$ mimetik ve pan-Bcl-2 inhibitörü olarak AT-101 jenerik ismiyle geliştirilmiştir. Noxa ve Puma gibi proapoptotik proteinlerin potansiyel indükleyicisi olduğu yapılan in vitro çalışmalarda gösterilmiştir. Kemoterapi naiv $(n=221)$ metastatik (mKDPK) hastalara randomize şekilde standart dozlarda dosetaksel + prednizon + AT-101 veya yalnızca dosetaksel + prednizon verilmiştir. PSA değerlerinin azalması, progresyonsuz sağkalım (PFS) veya ortanca genel sağkalım (OS) değerleri açısından önemli farklılıklar görülmemiştir (15). Yakın bir zaman önce sonuçlanan, 55 mKDPK'li hastada yapılan faz 2 çalışmasında, primer anti-androjen monoterapisi olarak bikalutamid ve bikalutamid + AT-101 verilen hasta grupları karşılaştırıldığında; AT-101 kombinasyonunun standart tedaviye eklenebilmesi için klinik faydalarının daha çok geliştirilmesi gerekliliğine kanaat getirilmiştir (16).

\section{Anti-apoptotik Bcl-2 Proteinlerinin Diğer Küçük Molekül İnhibitörleri}

Diğer aday bileşikler [obatoklaz, sabotoklaz (GX-15-070), ABT737, navitoklaz (ABT-263), apogossypol, TW-37] sağkalım Bcl-2 ailesi üyelerini inhibe etmek için geliştirilmiştir $(17,18,19)$. Bu bileşikler; $\mathrm{Bcl}-2$ ailesi üyelerine bağlanma özgünlüğü, derecesi ve sayılarına göre birbirlerinden ayrılırlar. Xenograft fare modelinde, dosetaksel ve ABT-737 kombinasyon terapisinin önemli ölçüde PC3 tümör büyümesini inhibe ettiği görülmüştür. Ayrıca, ABT263, PC3 hücrelerinde kaspaz-9'u aktive etmesine rağmen, kaspaz-9 inhibisyonu beklenmedik bir şekilde kaspaz-8 bağımlı apoptosisi kolaylaştırmıştır (20). Bu bulgular göstermektedir ki, $\mathrm{BCl}-\mathrm{xL}$ inhibisyonu, dosetaksel dirençli PK hücrelerini dosetaksele karşı duyarlı hale getirmekte ve kaspaz-9 inhibe PK hücrelerinin içindeki Bcl-2 ailesi üyelerinin antagonizminin, kaspaz-8 bağımlı hücre ölümünü tetiklediği benzersiz bir apoptotik yolağı açığa çıkarmaktadır. Bcl-2 hedefli klinik çalışmalarda en sık karşılaşılan sorun trombositopeni olup; bu etki Bcl-2'ye karşı en seçici olan navitoklaz ve ABT-737 ajanları ile gerçekleştirilen uygulamalarda görülmüştür $(21,22)$. Pro-apoptotik $\mathrm{Bcl}-2$ proteinleri için geliştirilmekte olan bir diğer yaklaşım, proto-onkogen serin/ treonin protein (PIM) kinazın bloke edilmesidir. PIM kinazlar, Bad proteinini doğrudan fosforilleyerek ve inhibe ederek apoptozu gerçekleştirir. PIM kinaz inhibitörü olan SGI-1176 (Astex Pharmaceuticals), hormona refrakter PK'de çalışılmış, ancak, kardiyak toksisitesine neden olduğu için bu ilacın geliştirilmesi durdurulmuştur (23).

\section{Dışsal Yolak İnhibitörleri}

PK'nin tedavisinde androjen deprivasyonu ile TNF, FAS-L, TRAIL gibi bilinen üç ölüm reseptöründen birinin aktivasyonu ile kaspaz-8 aracılı apoptozis aktivasyonu amaçlanmaktadır. Bu mekanizmaya yönelik geliştirilmekte olan stratejilerden ilki, ölüm reseptörlerini aktive edecek monoklonal antikor geliştirilmesi; diğeri ise dışsal apoptozis inhibitörü hücresel FLICE-inhibitör proteinine karşı RNA antisens oligonükleotidi geliştirilmesidir
(24). Bu sınıftaki en ileri düzeydeki ilaç leksatumumab (Human Genome Sciences) insan agonistik monoklonal antikoru olup, TRAIL reseptörünü aktive eder. TRAIL-R2, TNF reseptör ailesi üyesidir ve aktivasyonu dışsal yolak aracılı apoptozisi uyarır. Faz 1 çalışmaları, leksatumumabın kemoterapötikler ile birlikte kullanılabilirliğini göstermiştir (25). PK hücre hatları ve modellerinin de dahil edildiği bir çalışmada, sorafenib ile birlikte hücre ölümünü indüklediği ve tümör gelişimini yavaşlattığı gözlenmiştir. Erken faz denemeleri devam etmekte olan bu apoptozis uyarıcı ajanların PK'de umut vaat ettiği belirtilmektedir (26).

\section{Dual İnhibitörler}

Apoptozis protein inhibitörleri (IAP), kaspazları inaktive ederek sağkalımı destekleyen proteinlerdir. Dolayısıyla, kaspaz aktivitesinin kontrol edilmesinde merkezi konumda bulunur ve aşırı ifade edilmesi malign transformasyon ile ilişkilidir. X-kromozom bağlantılı IAP'yi inhibe etmek için iki hedef yaklaşım vardır: XIAP mRNA'sını hedef alan antisens inhibitörleri ve endojen mitokondriyal IAP inhibitörlerini (SMAC) taklit eden küçük molekül pan-IAP antogonistleridir (2).

AEG35156 (Aegera Therapeutics), XIAP mRNA ifadesini engelleyen bir antisens moleküldür. PK modelinde, umut verici sonuçlar elde edilmiş olsa bile, ileri aşamalarda lenfoma ve miyeloid lösemi problemlerine neden olması üzerine, bu ajanla ilgili çalışmalar durdurulmuştur (27). Aynı şekilde HGS1029 (Human Genome Science), solid organ tümörlerinde pan-IAP inhibitörü olarak çalışılan bir moleküldür. Solid tümörlerde yapılan faz 1 çalışmasında, HGS1029 inhibitörünün tek başına uygulanması iyi tolere edilmiş ve CIAP-1 miktarı periferal mononükleer hücrelerde önemli ölçüde düştüğü kaydedilmiştir (28). Tedavi için hedef alınan diğer bir IAP ajanı survivindir. PK'de survivin proteininin aşırı ifadelenmesi anti-androjenlere karşı direnci düzenlemektedir. Hem dış hem de iç yolaktaki aktivatörlere (FAS ligandı, Bax aşırı ifadelenmesi, p53, kaspaz-3, kaspaz-7 ve kaspaz-8) bağlı olarak gerçekleştirilen survivin aktivasyonu apoptozu baskılar. LY2181308 (Eli Lilly), yeni modifiye edilmiş bir survivin inhibitörüdür. Bu antisens ajan, tümör dokularına yönlendirildiğinde survivin ifadesini baskıladığı ve survivin pozitif hücreleri elimine ettiği gösterilmiştir (29). KDPK'li 150 hastada yapılan faz 2 çalışmasında, dosetaksel + prednizon ve dosetaksel + prednizon + LY2181308 iki grup halinde hastalara uygulandığında PFS, OS, önceden tanımlanmış PSA türevi son noktaları, kısa ağrı envanteri (BPI) ve fonksiyonel PK terapi değerlendirilmesi (FACT-P) açılarından herhangi bir etkinlik farkı saptanmamıştır (30). Bir diğer survivin inhibitörü YM155 ile yapılan, 35 mKDPK hastadan ikisinde başarılı PSA yanıtı, diğer ikisinde $\% 50<$ PSA düşüşü gözlenmiş ve dosetakselle kombine tedavisinde olumlu sonuçlar alınmıştır (31). AT-406 (Ascenta Therapeutics) için, faz 1 aşamasında denemelere devam edilmektedir (32). Bir diğer tedavi yaklaşımı, doğal IAP inhibitörleri olan moleküllerin hedeflenmesidir. SMAC proteinleri, mitokondriyal proteinlerdir ve IAP'lere bağlanarak onları inaktive ederler. Mitokondri geçirgenliğinde değişim olması sonucu salınırlar (2). SMAC proteinleri taklit eden bir molekül olan GDC-0152 (Genentech), lokal ileri veya metastatik malignensilerde çalışılmıştır. Çalışma 2010 yılında sonuçlandırılmış ancak henüz bu sonuçlar paylaşılmamıştır (2). 
LCL161 (Novartis), IAP'lere yüksek affinite ile bağlanarak cIAP1 ve cIAP2 yıkımını gerçekleştiren SMAC proteinini taklit eden ajandır. Paklitaksel + LCL161 kombinasyonu faz 1 çalışması tamamlanmıştır (33). TL32711 (Tetralogic Pharm) diğer bir SMAC proteinini taklit eden ajandır ve faz $1 / 2$ denemeleri devam etmektedir (2).

\section{Antişaperon Ajanlar}

Hormon terapi, radyoterapi, kemoterapi gibi standart kanser terapilerini içeren hücresel streslere yanıt olarak up-regüle olan sitoprotektif şaperon proteinlerin, tedaviye dirençte büyük rol oynadığı bilinmektedir. Yapılan çalışmalarda, hücrelerin apoptotik uyaranlara karşı stabilizasyonunda rol oynayan HSP27 ve clusterin şaperon proteinlerin aşırı ifadelenmesinin PK ile bağlantılı olduğu rapor edilmiştir $(34,35,36,37,38,39,40)$. HSP'ler, pek çok steroid reseptörün katlanmasında, aktivasyonunda, hücre içi trafiğinde ve transkripsiyonel aktivitelerinin düzenlenmesinde rol alırlar. ATP bağımsız çalışan HSP27, bir kez fosforile olup aktive olduğunda şaperonlayıcı oligomerizasyonu ile pek çok hücre yaşamsal faaliyetini düzenler. HSP27'nin, PK'nin başlangıcından kastrasyona dirençli evresine kadar geçen her bir aşamada ifadelenme düzeyi artar. Bu aşırı ifadelenmesi, kötü prognoz ve kastrasyona direnç süreci ile paralellik gösterir. Antişaperon ajanların apoptoz inhibisyon mekanizması; kaspaz aktivasyonunu ve sitokrom $C$ salınımını önlemeyi, nükleer faktör kappa B (NFKB) aktivasyonunu indüklemeyi kapsamaktadır (41). OGX-427 (Apatorsen), ikinci nesil 2'metoksietil kimyasal modifikasyonları içeren bir antişaperon ajandır. Bu kimyasal modifikasyon sayesinde aralıklı doz uygulamalarında degredasyonu engellenir. Doğal fosfodiester bağı yapan oligonükleotidler, hücresel nükleazlar ile hızlı bir şekilde yıkıı. Fosfodiester bağı oluşumuna katılmayan oksijen atomunun, sülfür ile yer değiştirmesi oligonükleotidi nükleaz degredasyonundan korur. Ancak, genel olarak fosfodiester bağı ile oluşturulan eşine göre hedef dizilere daha düşük affinite ile bağlanır. OGX-427'nin, HSP27 ekspresyonunu inhibe ederek PK gelişimini engellediği yapılan çalışmalarda gösterilmiştir. Kemoterapi naiv mKDPK hastalarında gerçekleştirilen faz 2 çalışmasında, OGX-427 + prednizon ve tek başına prednizon kullanımı sonucunda, kombinasyon tedavisinde $\% 40$ oranında 12 haftalık progresyonsuzluk dönemi gözlemlenmiştir. Hastaların yarııında, PSA düzeyinde \%50 üzerinde azalma da görülmüştür (42). Ayrıca, yan etkiler tolere edilebilir düzeyde saptanmıştır. Abirateron asetat ile OGX-427'nin kombine edildiği devam etmekte olan başka bir faz 2 çalışmasının yakın bir gelecekte sonuçlanacağı öngörülmektedir (43).

Stres indüklü bir diğer şaperon olan clusterin, hücreleri apoptosize içsel, dışsal ve birçok büyüme faktörü aracılığıyla götürür. Bax inhibisyonu, PI3K/Akt aktivasyonu, artmış nükleer translokasyonu gibi anti-apoptotik rolleri bilinen clusterin proteininin aşırı ifadelenmesi, hormon ablasyonuna, kemoterapiye ve radyoterapiye direnç geliştirmeye neden olur. Özellikle, dosetaksel direncinden sorumlu olabileceği düşünülmektedir. Clusterin hücre yüzey reseptörleri ile etkileşerek pro-apoptotik sinyal iletimini engeller. Clusterin ayrıca endoplazmik retikulumdan sitozola proteinlerin geçişini sağlayarak protein agregasyonunu engeller ve p53 tarafından aktifleştirilen stres sinyallerini baskılayarak hücre sağkalımını destekler (44). Custirsen (OGX-011), clusterin mRNA'sına komplementer, ikinci jenerasyon 2'metoksietil modifiye fosforotiyoat antisens oligonükleotitdir. Lokalize PK'li olgularda neo-adjuvan hormon terapisi ile kombine edilen custirsen çalışması, azalan prostat clusterin miktarı ile artan apoptotik indeks arasındaki ilişkiyi gösteren ve faz 2 çalışmaları için kullanılabilecek aktif dozun $(640 \mathrm{mg}$ ) belirlendiği ilk klinik çalışmadır (45). Kemoterapi naiv 52 KDPK'li hastalarda yapılan faz 2 çalışmasında (46), dosetaksel/prednizon ve OGX-011 (640 $\mathrm{mg}$ ) (A grubu) ve yalnızca dosetaksel/prednizon uygulanan (B grubu) iki grup incelenmiştir. A grubunda clusterin miktarı \%26 düşerken, B grubunda $\% 0,9$ artmıştır. A grubunda PFS ve OS değerleri sırasıyla 7,3 ay ve 23,8 ay bulunurken; $B$ grubunda bu süreler sırasıyla 6,1 ve 16,9 aydır.

OGX-011 ve dosetaksel kombine tedavisinin tolere edilebilir olması, artan sağkalım süresiyle gösterilmiştir. Custirsenin, kemoterapi ile kombine edilerek denendiği iki faz 3 çalışması da devam etmektedir $(47,48)$.

\section{Sonuç}

Son 15 yıllık süreçte, apoptotik eşiği düşürmeyi amaçlayan uygun ajanların geliştirmesi ve kliniğe uyarlanması için yoğun çaba harcanmaktadır. Kompleks apoptotik mekanizmalar ve geliştirilen ilaçların yan etki profilinin olmasından dolayı bu ajanların hepsinde başarıya ulaşılamamıştır. Ancak, ikinci jenerasyon antişaperon ajanlarından OGX-427 ve custirsen, her üç apoptotik yolağa (iç, dış ve sağ kalım yolakları) da müdahale edebildiği için, PK tedavisinde klinik önemlerini sürdürmektedir. Kanser hücrelerinin savunmasını zayıflatmak ve tedavi direncinin üstesinden gelmek için, bu antişaperon ajanlarının diğer tedavi ajanlarıyla (abirateron asetat, enzalutamid, radyum-223 diklorür gibi) birlikte kullanımları, var olan tedavilerin etkinliğini ve devamlıı̆ını arttırarak, hasta sağkalımı ve tedaviye yanııı artmasına katkı sağlayabilir.

\section{Sorular}

1. Birincil ve ikincil tedavilere karşı gelişen dirençte, apoptotik etkinliği artırımak çıkış yolu olabilir mi?

2. Isı şok proteinleri HSP27 ve clusterin, çoklu mekanizmaları ile tedavide dirence yol açan terapötik hedefler midir?

3. Bir intrasellüler tümör sorunu olan kastrasyona dirençte antisens oligonükleotidler ek tedavi seçeneği olabilir mi?

Etik

Hakem Değerlendirmesi: Editörler kurulu tarafından değerlendirilmiştir.

\section{Yazarlık Katkıları}

Konsept: Ece Konaç, Sinan Sözen, Dizayn: Ece Konaç, Sinan Sözen, Veri Toplama veya Işleme: Ece Konaç, Sinan Sözen, Analiz veya Yorumlama: Ece Konaç, Sinan Sözen, Literatür Arama: Ece Konaç, Sinan Sözen, Yazan: Ece Konaç, Sinan Sözen. Çıkar Çatışması: Yazarlar bu makale ile ilgili olarak herhangi bir çıkar çatışması bildirmemiştir.

Finansal Destek: Çalışmamız için hiçbir kurum ya da kişiden finansal destek alınmamıştır. 


\section{Kaynaklar}

1. Agarwal N, Di Lorenzo G, Sonpavde G, Bellmunt J. New agents for prostate cancer. Ann Oncol 2014;25:1700-1709.

2. Zielinski RR, Eigl BJ, Chi KN. Targeting the apoptosis pathway in prostate cancer. Cancer J 2013;19:79-89.

3. Higano CS. Potential use of custirsen to treat prostate cancer. Onco Targets Ther 2013;6:785-797.

4. de Bono JS, Logothetis C], Molina A, et al. Abiraterone and increased survival in metastatic prostate cancer. $N$ Engl J Med 2011;364:1995-2005.

5. Konaç E, Sözen S. Prostat Kanserinin Tanı ve Tedavisinde Moleküler Biyolojinin Kullanım Alanları. Bull Urooncol 2014;13:228-235.

6. Sheridan C, Martin SJ. Commitment in apoptosis: slightly dead but mostly alive. Trends Cell Biol 2008;18:353-357.

7. Vucic D, Dixit VM, Wertz IE. Ubiquitylation in apoptosis: a posttranslational modification at the edge of life and death. Nat Rev Mol Cell Biol 2011;12:439-452.

8. Brunelle JK, Leatai A. Control of mitochondrial apoptosis by the $\mathrm{BCl}-2$ family. J Cell Sci 2009;122:437-441.

9. Karnak D, Xu L. Chemosensitization of prostate cancer by modulating Bcl-2 family proteins. Curr Drug Targets 2010;11:699-707.

10. Mohammad RM, Muqbil I, Lowe L, et al. Broad targeting of resistance to apoptosis in cancer. Semin Cancer Biol 2015;35(Suppl)78-103.

11. Puhr M, Hoefer J, Neuwirt H, et al. PIAS1 is a crucial factor for prostate cancer cell survival and a valid target in docetaxel resistant cells. Oncotarget 2014;5:12043-12056.

12. Mouraviev V, Lee B, Patel V, et al. Clinical prospects of long noncoding RNAs as novel biomarkers and therapeutic targets in prostate cancer. Prostate Cancer Prostatic Dis 2016;19:14-20.

13. Mehrotra S, Languino LR, Raskett CM, et al. IAP regulation of metastasis. Cancer Cell 2010;17:53-64.

14. Sternberg $\mathrm{CN}$, Dumez $\mathrm{H}$, Van Poppel $\mathrm{H}$, et al. Docetaxel plus oblimersen sodium (Bcl-2 antisense oligonucleotide): an EORTC multicenter, randomized phase II study in patients with castrationresistant prostate cancer. Ann Oncol 2009;20:1264-1269.

15. Sonpavde G, Matveev V, Burke JM, et al. Randomized phase II trial of docetaxel plus prednisone in combination with placebo or AT101, an oral small molecule Bcl-2 family antagonist, as first-line therapy for metastatic castration-resistant prostate cancer. Ann Oncol 2012;23:1803-1808.

16. Stein MN, Hussain M, Stadler WM, et al. A Phase II Study of AT-101 to Overcome Bcl-2-Mediated Resistance to Androgen Deprivation Therapy in Patients With Newly Diagnosed Castration-Sensitive Metastatic Prostate Cancer. Clin Genitourin Cancer 2016;14:22-27.

17. Dash R, Azab B, Quinn BA, et al. Apogossypol derivative BI97C1 (Sabutoclax) targeting Mcl-1 sensitizes prostate cancer cells to mda-7/IL-24-mediated toxicity. Proc Natl Acad Sci USA 2011;108:8785-8790.

18. Jackson RS 2nd, Placzek W, Fernandez A, et al. Sabutoclax, a Mcl-1 antagonist, inhibits tumorigenesis in transgenic mouse and human xenograft models of prostate cancer. Neoplasia 2012;14:656-665.

19. Nguyen M, Cencic R, Ertel F, et al. Obatoclax is a direct and potent antagonist of membrane-restricted $\mathrm{Mcl}-1$ and is synthetic lethal with treatment that induces Bim. BMC Cancer 2015;15:568.

20. Tamaki $\mathrm{H}$, Harashima N, Hiraki $\mathrm{M}$, et al. Bcl-2 family inhibition sensitizes human prostate cancer cells to docetaxel and promotes unexpected apoptosis under caspase- 9 inhibition. Oncotarget 2014;5:11399-11412.
21. Roberts AW, Seymour JF, Brown JR, et al. Substantial susceptibility of chronic lymphocytic leukemia to BCL2 inhibition: results of a phase I study of navitoclax in patients with relapsed or refractory disease. J Clin Oncol 2012;30:488-496.

22. Debrincat MA, Pleines I, Lebois $M$, et al. BCL-2 is dispensable for thrombopoiesis and platelet survival. Cell Death Dis 2015;6:1721.

23. National Institutes of Health. Safety of SGI-1776, a PIM kinase inhibitor in refractory prostate cancer and relapsed/refractory non Hodgkin's lymphoma.

24. Nastiuk KL, Krolewski JJ. FLIP-ping out: death receptor signaling in the prostate. Cancer Biol Ther 2008;7:1171-1179.

25. Wakelee $\mathrm{HA}$, Patnaik $\mathrm{A}$, Sikic $\mathrm{BI}$, et al. Phase I and pharmacokinetic study of lexatumumab (HGS-ETR2) given every 2 weeks in patients with advanced solid tumors. Ann Oncol 2010;21:376-381.

26. Abdulghani J, Allen JE, Dicker DT, et al. Sorafenib sensitizes solid tumors to Apo2L/TRAIL and Apo2L/TRAIL receptor agonist antibodies by the Jak2-Stat3-Mcl1 axis. PLoS One 2013;8:75414.

27. Dean E, Jodrell D, Connolly K, et al. Phase I trial of AEG35156 administered as a 7-day and 3-day continuous intravenous infusion in patients with advanced refractory cancer. J Clin Oncol 2009;27:1660-1666.

28. Fulda S. Promises and Challenges of Smac Mimetics as Cancer Therapeutics. Clin Cancer Res 2015;21:5030-5036.

29. Zhang M, Latham DE, Delaney MA, Chakravarti A. Survivin mediates resistance to antiandrogen therapy in prostate cancer. Oncogene 2005;24:2474-2482.

30. Wiechno P, Somer BG, Mellado B, et al. A randomised phase 2 study combining LY2181308 sodium (survivin antisense oligonucleotide) with first-line docetaxel/prednisone in patients with castrationresistant prostate cancer. Eur Urol 2014;65:516-520.

31. Tolcher AW, Quinn DI, Ferrari A, et al. A phase II study of YM155, a novel small-molecule suppressor of survivin, in castration-resistant taxane-pretreated prostate cancer. Ann Oncol 2012;23:968-973.

32. National Institutes of Health. Dose escalation study of safety and tolerability of AT-406 in patients with advanced solid tumors and lymphomas.

33. National Institutes of Health. A study of LCL161 in combination with weekly paclitaxel in adult patients with advanced solid tumors.

34. Katsogiannou M, Andrieu C, Baylot V, et al. The functional landscape of Hsp27 reveals new cellular processes such as DNA repair and alternative splicing and proposes novel anticancer targets. Mol Cell Proteomics 2014;13:3585-3601.

35. Stope $M B$, Weiss $M$, Preuss $M$, et al. Immediate and transient phosphorylation of the heat shock protein 27 initiates chemoresistance in prostate cancer cells. Oncol Rep 2014;32:2380-2386.

36. Cordonnier T, Bishop JL, Shiota M, et al. Hsp27 regulates EGF/ $\beta$ catenin mediated epithelial to mesenchymal transition in prostate cancer. Int J Cancer 2015;136:496-507.

37. Stope MB, Peters $S$, Großebrummel $H$, et al. Androgen receptor (AR) inhibitor ErbB3-binding protein-1 (Ebp1) is not targeted by the newly identified AR controlling signaling axis heat-shock protein HSP27 and microRNA miR-1 in prostate cancer cells. World J Urol 2015;33:323-327.

38. Voll EA, Ogden IM, Pavese JM, et al. Heat shock protein 27 regulates human prostate cancer cell motility and metastatic progression. Oncotarget 2014;5:2648-2663.

39. Lamoureux F, Thomas C, Yin MJ, et al. Suppression of heat shock protein 27 using OGX-427 induces endoplasmic reticulum stress and potentiates heat shock protein 90 inhibitors to delay castrateresistant prostate cancer. Eur Urol 2014;66:145-155.

40. Yamamoto Y, Lin PJ, Beraldi E, et al. siRNA Lipid Nanoparticle Potently Silences Clusterin and Delays Progression When Combined with Androgen Receptor Cotargeting in Enzalutamide-Resistant Prostate Cancer. Clin Cancer Res 2015;21:4845-4855. 
41. De Maeseneer DJ, Van Praet C, Lumen N, Rottey S. Battling resistance mechanisms in antihormonal prostate cancer treatment: Novel agents and combinations. Urol Oncol 2015;33:310-321.

42. Chi KN, Hotte SJ, Ellard S, et al. A randomized phase II study of OGX-427 plus prednisone ( $P$ ) versus $P$ alone in patients (pts) with metastatic castration resistant prostate cancer (CRPC). J Clin Oncol 2012;30(Suppl):4514.

43. National Institutes of Health. OGX-427 in metastatic castrateresistant prostate cancer with prostate-specific antigen progression while receiving abiraterone.

44. Zhong B, Sallman DA, Gilvary DL, et al. Induction of clusterin by AKT-role in cytoprotection against docetaxel in prostate tumor cells. Mol Cancer Ther 2010;9:1831-1841.
45. Chi KN, Eisenhauer E, Fazli L, et al. A phase I pharmacokinetic and pharmacodynamic study of OGX-011, a 2'-methoxyethyl antisense oligonucleotide to clusterin, in patients with localized prostate cancer. J Natl Cancer Inst 2005;97:1287-1296.

46. Chi KN, Hotte SJ, Yu EY, et al. Randomized phase II study of docetaxel and prednisone with or without OGX-011 in patients with metastatic castration-resistant prostate cancer. J Clin Oncol 2010;28:4247-4254.

47. National Institutes of Health. Comparison of docetaxel/prednisone to docetaxel/prednisone in combination with OGX-011 in men with prostate cancer (SYNERGY).

48. National Institutes of Health. Comparison of cabazitaxel/prednisone alone or in combination with custirsen for 2 nd line chemotherapy in prostate cancer (AFFINITY). 